\title{
THE DEVELOPMENT OF RETAIL STORE TYPES IN THE CONTEXT OF REGION AND CONSUMER BEHAVIOUR
}

\author{
Ieva Andersone ${ }^{1}$ Rita Greitane ${ }^{2}$ \\ Riga Technical University (Latvia)
}

\begin{abstract}
The aim of the article is to analyze the prevalence of retail stores in Latvian regions and consumer behavior in Latvia. The authors have analyzed the prevalence of largest retail stores in regions and consumer behavior in retail using available statistical data and research done by the authors. As a result of the study, the role of shop assistants was determined during the purchasing process, and the results of the study have been compiled from the viewpoint of generations. These results can help retail companies to work more effectively by choosing the most appropriate retail store types

KEY WORDS: Consumer behavior, Retailing, Retail store types, Generation.
\end{abstract}

JEL CODES: M11, M31, F1

DOI: http://dx.doi.org/10.15181/rfds.v14i3.859

\section{Introduction}

Research problem: Latvia saw one of the highest increases in retail sales in 2013. Persisting macroeconomic stability and rising real disposable incomes resulted in higher private spending, which was one of the main contributors to the country's GDP over the review year. Lower income tax and rising real wages resulted in higher real disposable incomes in 2013 and improved consumer confidence, thus encouraging people to spend more on discretionary goods, both in the grocery and non-grocery sector. Non-grocery retailers outperformed their grocery peers in 2013, mainly thanks to a further improvement in customer purchasing power which in turn shaped buyer preferences in favour of larger purchases that were not affordable during the economic downturn. Despite the growth of non-store retailing, traditional retailing in stores has held its positions. Therefore, it is important to recognize store types and their development trends.

Research purpose is to produce recommendations for store development in regions using statistical data and the study made by the authors.

Research object are particularities of consumer behaviour and retail stores in Latvia.

The main goal is to analyze the prevalence of store types in the regions of Latvia. The study attributes particular importance to the role of shop assistants and their influence on the decision making of customers during the purchasing process.

Ieva Andersone - lecturer, Riga Technical University, Faculty of Engineering Economics and Management. Scientific interests: marketing, consumer behaviour

E-mail: ieva.andersone@rtu.lv

Tel.: +371 67608647

2 Rita Greitane - lecturer, Riga Technical University, Faculty of Engineering Economics and Management. Scientific interests: marketing, consumer behaviour

E-mail: rita.greitane@rtu.lv

Tel.:+37167608647 
Research tasks are to analyze statistical data of retailing and retail stores in regions; to analyze the importance of shop assistants and what the seller does correctly or incorrectly; to establish division of generations and their proportions in Latvia; to develop decision making tools for retailing companies.

Research methods: The authors employ well-known methods of research - analysis and synthesis methods, grouping, comparison etc.

\section{Development of retail stores in Latvia}

Latvia saw one of the highest increases in retail sales in 2013. Persisting macro-economic stability and rising real disposable incomes resulted in higher private spending, which was one of the main contributors to the country's GDP over the review year. Increasing private spending encouraged retailers to open new stores and expand their assortments with higher-priced grocery and non-grocery goods, thereby providing additional stimulus to retail sales growth. Lower income tax and rising real wages resulted in higher real disposable incomes in 2013 and improved consumer confidence, thus encouraging people to spend more on discretionary goods, both in the grocery and non-grocery sector. Non-grocery retailers outperformed their grocery peers in 2013, mainly thanks to a further improvement in customer purchasing power which in turn shaped buyer preferences in favour of larger purchases that were not affordable during the economic downturn. Higher disposable incomes enabled Latvians to renew spending on electronics, home appliances and home improvement products, thereby stimulating overall non-grocery growth. An additional boost to non-grocery sales came from customers' willingness to improve their appearance by buying new apparel, footwear and beauty products. With a value share of $10 \%$, Depo DIY SIA was the leading player in non-grocery retailers in 2013. The company's strong position can mainly be attributed to its large stores which offer a broad variety of goods, ranging from home improvement and gardening to food and pets. (Euromonitor, 2014) These tendencies can be seen by examining the net turnover share in trade shown in Table 1.

Table 1. Net turnover share in trade for $2012, \%$

\begin{tabular}{|l|c|}
\hline \multicolumn{1}{|c|}{ Trade } & Net turnover share, $\mathbf{~}$ \\
\hline Food and beverage & 55 \\
\hline Home and garden & 22 \\
\hline Equipment and suupplies for office and production & 7,8 \\
\hline Clothing, footwear and accessories & 5,5 \\
\hline The rest & 10 \\
\hline
\end{tabular}

Source: Statistical data, 2014

Meanwhile, the dominating grocery players, Rimi Latvia SIA and Maxima Latvija SIA, enlarged their non-grocery assortments, especially in supermarkets and hypermarkets, in order to defend their market share from non-grocery rivals. Maxima Latvija SIA runs sales through conveniences stores, supermarkets and hypermarkets while Rimi Latvia SIA operates through Supernetto discounters, supermarkets and hypermarkets. Both grocery retail chains compete for the leading position in the market by attempting to provide the best possible prices, large discounts and comprehensive loyalty programmes. Companies are regularly running massive advertising campaigns via TV, outdoor media and the internet. (Euromonitor, 2014) Store-based retailing is expected to perform healthily over the forecast period and record modest growth rates as the Latvian economy stabilises. The non-grocery channel is projected to see slightly faster expansion compared to grocery retailing as consumers will allocate a major portion of rising real disposable incomes to discretionary items. In contrast, non-store retailing is predicted to continue to record rapid annual growth rates thanks to the surging popularity of shopping over the internet (Euromonitor, 2014). The increasing use of smartphones and tablet computers fuelled growth within non-grocery retailing during 2013. Internet retailer 220.1v SIA was the leading player in 2013, accounting for $8 \%$ of total non-store retailing value sales. The company managed to outperform previous market leader direct seller Avon Cosmetics Latvia SIA, mainly due to the 
increasing popularity of shopping online and soaring demand for electronics and appliances. It should be noted that 220.lv SIA has a very broad product assortment ranging from fragrances and child goods to furniture and sports (Euromonitor, 2014).

Despite the growth of non-store retailing, traditional retailing in stores has held its positions. Therefore, it is important to recognize store types and their development trends. However, there is no unique method of categorizing retailers.

Some studies (e.g. Jin and Kim, 2003; Arnold and Reynold, 2003; Geuens, Brengman and Rosette, 2001; Bloch, Ridgway and Dawson, 1994) provide evidence that shoppers patronise diverse store formats as they find an opportunity to interact with others as well as store personnel, share their experience and knowledge with others, and bond with others at store format (Jayasankaraprasad and Kathyayani, 2013: 9).

The authors will use the conventional classification method of retail stores based on their size and assortment. These include malls (shopping centers), hypermarkets, department stores, supermarkets, specialized supermarkets, warehouse stores, specialized stores, convenience stores (neighbourhood stores), boutiques, pop-up stores, discounters and express stores (Berman, Evans, 2003: 280-282; Newman, Cullen, 2005: 24-27). The article will analyse the most widespread retail store types, such as hypermarkets, supermarkets, convenience stores (neighbourhood stores), in Latvia as a whole and in its regions. The largest members of the market which represent these retail store types are Rimi, Maxima, Top, AIBE and LaTS. Their turnover and profits/losses have been summarised in Table 2 .

Table 2. Financial data of largest retailers (thsd lats/thsd euro)

\begin{tabular}{|l|l|c|c|}
\hline \multirow{2}{*}{ Retailer } & Year & Turnover (thsd lats/thsd euro) & Profit/loss (thsd lats/ thsd euro) \\
\hline Maxima & 2012 & $450368.000 / 640815.931$ & $14342.000 / 20406.828$ \\
\hline & 2011 & $413210.000 / 587944.861$ & $1870.000 / 2660.770$ \\
\hline & 2010 & $390450.000 / 555560.298$ & $10700.000 / 15224.728$ \\
\hline Rimi & 2012 & $443326.000 / 630796.068$ & $8950.000 / 12734.703$ \\
\hline & 2011 & $417160.000 / 593565.205$ & $6345.000 / 9028.122$ \\
\hline & 2010 & $391800.000 / 557481.175$ & $5228.000 / 7438.774$ \\
\hline top! & 2012 & $7980.000 / 11354.517$ & $19.994 / 28.449$ \\
\hline & 2011 & $5490.000 / 7811.566$ & $6.363 / 9.054$ \\
\hline AIBE & 2010 & $4100.000 / 5833.774$ & $0.068 / 0.097$ \\
\hline & 2012 & $5940.000 / 8451.859$ & $-109.924 /-156.408$ \\
\hline & 2011 & $4895.697 / 6965.949$ & $-77.893 /-110.832$ \\
\hline & 2010 & $4200.000 / 5976.062$ & data \\
\hline
\end{tabular}

Source: www.nozare.lv 2014

In the study "101 most valuable Latvian enterprise" done by the business idea magazine "Kapitāls", IBS Prudentia and Riga Fund stock exchange in 2012 "Maxima Latvija" (with a value of Ls 174.1 million on the 01.01.2012) was in 10th place, whereas in the 2013 study (with a value of Ls 173.4 million on the 01.01.2013) it was in 11th place. Their largest competitor "Rimi Latvia" in the 2012 and 2013 studies with a value of Ls 131.5 million on the 01.01.2012 and a value of Ls 141.7 million on the 01.01.2013 was in the 16th place (www.nozare.lv, 2014).

There are 196 food stores operating under the trademark top!, 99 of which are top! and 97 mini top! stores owned by 17 local enterprises (April 2014): "Firma Madara 89", LLC, JSC “LPB”, JSC "Diāna", "Lars Limited" LLC, "Gabriēla" LLC, "Dekšņi”" LLC, "Mārksmens" LLC, "Madara 93" LLC, "AA \& Co" LLC, "Krista - A” LLC, JSC "Roga - Agro", "ESSA” LLC, "G.A.L.” LLC, "Lekon" LLC, "Ogres Prestižs" LLC, "Pārtikas veikalu grupa" LLC and "Oregano" LLC. "Iepirkuma grupa" LLC is the enterprise that represents the supermarket chain top! and provides for joint purchasing procedures and common marketing activities for the whole supermarket chain. (www. toppartika.lv). In contrast, "Latvijas tirgotāju kooperācija AIBE" is an enterprise with international 
experience. Its founders are not only Latvian entrepreneurs and the trading camera, but also the cooperation "Aibe mažmena" in Lithuania. At the moment there are around 450 stores in Latvia, which operate in various Latvian regions as part of AIBE.

Rimi and Maxima are represented in the hypermarket, supermarket, convenience store and discounter segments, whereas top! and AIBE operate mostly in the convenience store segment.

The entry and increasing activity of large supermarket chains in the convenience store segment in various regions in Latvia shows both that these regions are becoming more appealing and that the supermarket chains are willing to strengthen their positions in this retail segment. Turnover, staff costs and number of employees according to region are shown in Table 3.

Table 3. Main entrepreneurship indicators in trade by statistical region for 2010-2011

\begin{tabular}{|c|c|c|c|c|c|c|c|}
\hline \multirow[b]{3}{*}{ Trade } & \multirow{3}{*}{ Region } & \multicolumn{6}{|c|}{ Indicators } \\
\hline & & \multicolumn{3}{|c|}{2010} & \multicolumn{3}{|c|}{2011} \\
\hline & & \begin{tabular}{|c|} 
Turnover \\
(thsd euro)
\end{tabular} & $\begin{array}{c}\text { Personal } \\
\text { costs (thsd } \\
\text { euro) }\end{array}$ & $\begin{array}{c}\text { Number } \\
\text { of persons } \\
\text { employed }\end{array}$ & $\begin{array}{c}\text { Turnover } \\
\text { (thsd euro) }\end{array}$ & $\begin{array}{c}\text { Personal } \\
\text { costs (thsd } \\
\text { euro) }\end{array}$ & $\begin{array}{c}\text { Number } \\
\text { of persons } \\
\text { employed }\end{array}$ \\
\hline \multirow{6}{*}{$\begin{array}{l}\text { Wholesale and } \\
\text { retail trade; repair } \\
\text { of motor vehicles }\end{array}$} & Riga region & 13149341 & 592882 & 86132 & 15145932 & 604808 & 80072 \\
\hline & Pieriga region & 2255263 & 150154 & 23774 & 2591351 & 155979 & 21944 \\
\hline & Vidzeme region & 578355 & 37000 & 9009 & 568641 & 36121 & 8286 \\
\hline & Kurzeme region & 725000 & 42872 & 10333 & 1005471 & 50438 & 10991 \\
\hline & Zemgale region & 867594 & 41862 & 10023 & 1024269 & 45084 & 9491 \\
\hline & Latgale region & 512566 & 37738 & 12275 & 619538 & 40770 & 11479 \\
\hline \multirow{6}{*}{$\begin{array}{l}\text { Retail trade, except } \\
\text { of motor vehicles } \\
\text { and motorcycles }\end{array}$} & Riga region & 3379139 & 251563 & 45059 & 3436765 & 262780 & 42868 \\
\hline & Pieriga region & 1022969 & 92135 & 16652 & 1016873 & 92921 & 14885 \\
\hline & Vidzeme region & 245180 & 24530 & 6237 & 231154 & 22451 & 5585 \\
\hline & Kurzeme region & 276083 & 26602 & 7245 & 342175 & 32657 & 8044 \\
\hline & Zemgale region & 304158 & 27719 & 7007 & 363038 & 29621 & 6930 \\
\hline & Latgale region & 262337 & 27794 & 9085 & 283136 & 29435 & 8556 \\
\hline
\end{tabular}

Source: Statistical data, 2014

From Table 3 it is evident that the lowest trade figures are in the Latgale and Vidzeme regions, whereas the best figures are in the Riga and Pieriga regions. Respectively, staff costs are the highest in the Riga and Pieriga regions and the lowest in Latgale and Vidzeme regions but turnover per retail employee is the highest in the Riga region, the lowest in the Vidzeme region.

The number of Rimi, Maxima, top! and AIBE stores in regions is shown in Table 4.

Table 4. Number of shops of Maxima and Rimi by statistical region

\begin{tabular}{|c|c|c|c|c|c|c|c|c|}
\hline \multirow[b]{2}{*}{ Region } & \multicolumn{3}{|c|}{ Maxima } & \multirow[b]{2}{*}{ Total } & \multicolumn{3}{|c|}{ Rimi } & \multirow[b]{2}{*}{ Total } \\
\hline & $\begin{array}{c}\text { XXX } \\
\text { hyper- } \\
\text { market }\end{array}$ & $\begin{array}{c}\text { XX super- } \\
\text { market }\end{array}$ & $\begin{array}{l}\text { X neighbour- } \\
\text { hood store }\end{array}$ & & $\begin{array}{l}\text { Hyper- } \\
\text { market }\end{array}$ & $\begin{array}{l}\text { Super- } \\
\text { market }\end{array}$ & $\begin{array}{c}\text { Supernetto } \\
\text { (discounter) }\end{array}$ & \\
\hline Riga region & 3 & 5 & 47 & 55 & 12 & 21 & 24 & 57 \\
\hline Pieriga region & - & 6 & 18 & 24 & 4 & 3 & 8 & 15 \\
\hline Vidzeme region & - & 5 & 11 & 16 & - & 2 & 5 & 7 \\
\hline Kurzeme region & - & 4 & 12 & 16 & 2 & 6 & 6 & 14 \\
\hline Zemgale region & - & 3 & 11 & 14 & 2 & 2 & 7 & 11 \\
\hline Latgale region & - & 3 & 16 & 19 & 1 & 3 & 5 & 9 \\
\hline Total & 3 & 26 & 115 & 144 & 21 & 37 & 55 & 113 \\
\hline
\end{tabular}

Source: www.rimi.lv, www.maxima.lv, 2014 
It can be seen from Table 4 that the strategy of Maxima is oriented towards opening hypermarkets only in Riga, whereas Rimi also has hypermarkets outside Riga, except the Vidzeme region.

The number of stores of top! and AIBE in regions is shown in Table 5.

Table 5. Number of shops of Top! And AIBE by statistical region

\begin{tabular}{|c|c|c|c|c|}
\hline Region & \multicolumn{2}{|c|}{ Top! } & Total & AIBE \\
\cline { 3 - 4 } & $\begin{array}{c}\text { supermarket } \\
\text { (top) }\end{array}$ & $\begin{array}{c}\text { convenience } \\
\text { store (mini) }\end{array}$ & & $\begin{array}{c}\text { convenience } \\
\text { store }\end{array}$ \\
\hline Riga region & 5 & - & 5 & 37 \\
\hline Pieriga region & 15 & 13 & 28 & 18 \\
\hline Vidzeme region & 25 & 25 & 50 & 18 \\
\hline Kurzeme region & 29 & 45 & 74 & 4 \\
\hline Zemgale region & 14 & 5 & 19 & 41 \\
\hline Latgale region & 7 & 7 & 14 & 45 \\
\hline Total & 95 & 95 & 190 & 163 \\
\hline
\end{tabular}

Source: www.top.lv, www.aibe.lv, 2014

Most of AIBE stores are located in Latgale, Zemgale and Riga regions but top! stores - in Kurzeme and Vidzeme regions.

\section{Consumer behaviour in retail}

The study results can be analysed and interpreted from various perspectives but in order to achieve the aim of the study the survey results were summarised by dividing all respondents into generations. Generations which have been surveyed during the study are (Levy, 1998: 98-104):

- "Net" generation: 0-19 years old;

- "Y" generation: 20-30 years old;

- "X" generation: 31-45 (50) years old;

- "Post-war" generation: 51-62 years old;

- "Silver" generation: older than 63 years.

A questionnaire was made to carry out the reasearch. When answering questions about whether or not the shop assistant, when selling a good in a shop, influences customer decision about buying the good, $50 \%$ of respondents answered positively, whereas $48 \%$ thought that the actions of the shop assistant influence them rarely.

When compiling answers about what is done incorrectly in stores, respondents indicated that the shop assistant:

- is impolite, communicates very little or does not communicate at all. A contrasting opinion was also expressed that shop assistants are too active and insistent with their offers;

- $\quad$ are willing to help as soon as the customer has entered the store without having the chance to see the assortment;

- $\quad$ is in a bad mood, is impatient;

- often is busy with his/her own affairs, chats, eats, argues, plays videogames and so on;

- enforces his/her own opinion, is too persistent, does not give the customer the chance to assess the good on his/her own;

- stands next to the customer and observes him/her, follows the customer like a shadow, thinks of the customer as a potential thief;

- $\quad$ is not interested in selling;

- is not knowledgeable about the assortment of goods and their applications, often is incompetent;

- does not like if the customer touches the good with his/her hands but ultimately does not purchase it (more applicable to clothing stores) and so on. 
After analysing the answers, the authors conclude that Latvian customers pay attention, analyse and observe the work of shop assistants. Customers form their opinion about the company according to the actions of the shop assistant, who thus forms the overall image of the company. During more detailed interviews customers revealed that it is very difficult to change the negative experience they have had and very often information about their negative experience is spread within the social class of the customer through word of mouth.

The results of the study also indicated positive experience during shopping and that this experience encourages repeated purchases. This validates the assumption of the authors that the sales assistant plays a very important role in the process of purchasing goods. Taking into account theories of determining and analysing customer needs, it can be concluded that any complaint encompasses potential needs. The authors would like to emphasize that, when analysing customer complaints, a list of customer needs can be constructed, which can be used by shop assistants working in the store. This approach to shop assistant training can ensure that the actions of shop assistants are oriented towards satisfying customer needs and expectations.

Respondents also mentioned various situations when during selling something was not done correctly or when the customer did not benefit from the purchase. Therefore, in order to clarify how often this happens, various specific questions were asked.

The "Net" generation said that sometimes the shop assistant convinces them to make a purchase. In addition, occasionally a purchase is made only because the good was well-position in the store. According to the "Net" generation, the layout of shops is important, but the shop assistant can rarely convince them to purchase a good which will not benefit them economically or socially. Respondents have also noted that sometimes conflict situations arise with the shop assistant, and that $50 \%$ of the time the cause is due to the shop assistant and $50 \%$ of the time the cause is due to the customer or various external factors. However, it is clear that the opinion of the shop assistant could differ from the opinion of the customer.

The answers of the "Y" generation were similar, but some slight differences could be noticed. Respondents in this generation said that they have occasionally purchased a good if it is well-positioned in the store. They also noted that the layout of the store always plays a role in the purchasing process and choice of goods. The shop assistant rarely influences them; however, sometimes conflict situations arise. According to the "Y" generation, the cause of these situations is more often the customer rather than the shop assistant. 55\% of the respondents have noted that the conflict is caused by various external factors. Respondent answers indicate that the "Y" generation is characterized by social maturity and the ability to individually make wellgrounded decisions. It is possible that the "Y" generation carefully plans its expenditure and does not make unreasoned purchases.

After studying the answers given by the " $\mathrm{X}$ " generation to the aforementioned questions, it can be concluded that shop assistants sometimes convince this generation to make a purchase and that members of this generation often purchase goods if they are well-positioned in the store. This generation considers that store layout is more important than shop assistant influence. Conflict situations, which occur rarely (this is a sound indicator based on the age group and social experience of this generation), are more often initiated by customers themselves, but more rarely by shop assistants or various external factors.

The Silver and Post-war generations have mutually similar views; however, they are not identical.

Summarizing the results of the study, it can be concluded that: when the age of the customer changes (according to the indicated generations), the influence of the shop assistant on the decison to make a purchase changes as well. As the age increases, the influence of the shop assistant increases as well, whereas for younger customers a more important factor is the layout of the store.

This can be explained using various psychological, social, economic and other factors. It should be noted, however, that the habits of the new generation of consumers are changing and that the causes of these changes are directly or indirectly related to the development of information technologies and the internet.

The study confirms that, during the purchasing process, shop assistants, communication and other factors play an important role. 
By using the available statistical data about regions it is possible to determine the development trends of every region and find correlations with retail stores located there. Looking at the population statistics it can be seen that the Vidzeme region has the lowest population (only $10 \%$ of the whole population of Latvia); whereas half of the population lives in the Riga and Pieriga regions (see Table 6). Hence, all retail store types are widespread in these regions, and they have the largest number of hypermarkets and supermarkets.

Table 6. Number of inhabitants by statistical region

\begin{tabular}{|l|c|c|c|}
\hline & $\mathbf{2 0 1 1}$ & $\mathbf{2 0 1 2}$ & $\mathbf{2 0 1 3}$ \\
\hline \multicolumn{1}{|c|}{ LATVIA } & 2074605 & 2044813 & 2023825 \\
\hline Riga region & 659418 & 649853 & 643615 \\
\hline Pieriga region & 371952 & 370128 & 369987 \\
\hline Vidzeme region & 211995 & 208728 & 205949 \\
\hline Kurzeme region & 271143 & 266433 & 262755 \\
\hline Zemgale region & 255111 & 251495 & 248845 \\
\hline Latgale region & 304986 & 298176 & 292674 \\
\hline
\end{tabular}

Source: Statistical data, 2014

On the other hand, if the population is viewed in terms of its generations, it is seen that around $60 \%$ of people living in regions are working-age. This means that mostly they are people from the "X" and "Y" generations. If we look at the Silver generation, the size of this generation is increasing every year, and this is especially evident in regions.

Table 7. Population by sex and by main group by statistical region at the beginning of the year, $\%$

\begin{tabular}{|c|c|c|c|c|c|c|}
\hline & \multicolumn{3}{|c|}{$\mathbf{2 0 1 2}$} & \multicolumn{3}{c|}{$\mathbf{2 0 1 3}$} \\
\hline & $\begin{array}{c}\text { Under } \\
\text { working } \\
\text { age }\end{array}$ & $\begin{array}{c}\text { Of } \\
\text { working } \\
\text { age }\end{array}$ & $\begin{array}{c}\text { Over } \\
\text { working } \\
\text { age }\end{array}$ & $\begin{array}{c}\text { Under } \\
\text { working } \\
\text { age }\end{array}$ & $\begin{array}{c}\text { Of } \\
\text { working } \\
\text { age }\end{array}$ & $\begin{array}{c}\text { Over } \\
\text { working } \\
\text { age }\end{array}$ \\
\hline LATVIA & 14,3 & 63,6 & 22,1 & 14,4 & 63,2 & 22,4 \\
\hline Riga region & 13,2 & 64,1 & 22,7 & 13,6 & 63,4 & 23 \\
\hline Pierīga region & 16,1 & 63,8 & 20,1 & 16,2 & 63,4 & 20,4 \\
\hline Vidzeme region & 14,1 & 63 & 22,9 & 14 & 62,8 & 23,2 \\
\hline Kurzeme region & 15,1 & 62,5 & 22,4 & 15,1 & 62,1 & 22,8 \\
\hline Zemgale region & 14,9 & 64 & 21,1 & 14,9 & 63,7 & 21,4 \\
\hline Latgale region & 13,3 & 63,4 & 23,3 & 13,3 & 63,1 & 23,6 \\
\hline
\end{tabular}

Source: Statistical data, 2014

Looking at people's incomes in regions, it is seen that the lowest average salary is in the Vidzeme region.

Table 8. Avarage monthly wages and salaries by statistical region of Latvia (in Euro)

\begin{tabular}{|l|l|c|c|c|c|}
\hline & & $\mathbf{2 0 1 0}$ & $\mathbf{2 0 1 1}$ & $\mathbf{2 0 1 2}$ & $\mathbf{2 0 1 3}$ \\
\hline Bruto & LATVIA & 633 & 660 & 685 & 716 \\
\hline & Riga region & 724 & 757 & 778 & 815 \\
\hline & Pieriga region & 603 & 622 & 649 & 677 \\
\hline & Vidzeme region & 485 & 518 & 528 & 560 \\
\hline & Kurzeme region & 544 & 559 & 598 & 608 \\
\hline
\end{tabular}




\begin{tabular}{|l|l|c|c|c|c|}
\hline & & $\mathbf{2 0 1 0}$ & $\mathbf{2 0 1 1}$ & $\mathbf{2 0 1 2}$ & $\mathbf{2 0 1 3}$ \\
\hline & Zemgale region & 508 & 547 & 571 & 597 \\
\hline \multirow{2}{*}{ Neto } & Latgale region & 440 & 468 & 475 & 490 \\
\hline & LATVIA & 450 & 470 & 488 & 516 \\
\hline & Riga region & 511 & 534 & 551 & 583 \\
\hline & Pieriga region & 429 & 447 & 466 & 491 \\
\hline & Vidzeme region & 351 & 376 & 384 & 410 \\
\hline & Kurzeme region & 392 & 404 & 430 & 441 \\
\hline & Zemgale region & 367 & 395 & 413 & 436 \\
\hline & Latgale region & 320 & 340 & 345 & 358 \\
\hline
\end{tabular}

Source: Statistical data, 2014

Taking the size of the population and people's incomes into account (see Table 8), the Vidzeme region is not attractive to the large retail chains Rimi and Maxima because there are relatively few of these stores in this region. On the other hand, Aibe, top! and LaTS convenience stores are more popular.

\section{Conclusions}

After analysing the study results, the authors conclude that the Latvian consumers pay attention to shop assistant work, they analyse and observe them. Depending on the shop assistant's behaviour, the buyer forms an opinion about the company and shop, hence shaping the overall image of the company. During in-depth interviews, people pointed out that it is difficult to change the negative experience, and often this negative experience is disseminated in the buyer's social layer through word of mouth.

The authors conclude that the shop arrangements, advertising of the goods at the point of sale, and shop assistant behaviour have a great impact during the purchasing process. It must be noted that the shop assistant's behaviour can decisively affect customer decision making during the purchasing process in particular age groups.

Looking at the main entrepreneurship indicators in trade, population size and people's incomes it can be concluded that retailers pay attention to economic and demographic parameters by choosing the store types which they open in each region.

\section{References}

Andersone, I., Gaile-Sarkane, E. (2009). Development of demand and consumption by generations. 5 International scientific conference "Social sciences in global world: possibilities, challenges and perspectives". Klaipèda University. Bridges, Vol. 39. Supplementary issue: scientific volume, p. 165-170.

Arnold, M. J., Reynolds, K. E. (2003). Hedonic Shopping Motivations. Journal of Retaling, Vol. 79 (1), p. $77-95$.

Bloch, P. H., Ridgway N. M., Dawson, S. A. (1994). The Shopping Mall as Consumer Habitat. Journal of Retailing, Vol. 70 (1), p. 23-42.

Central Statistical Bureau of Latvia. (2014). Avarage monthly wages and salaries by statistical region of Latvia. Available at: http://data.csb.gov.lv/Table.aspx?layout=tableViewLayout1\&px_tableid=DS0070m_euro.px\&px_ path=Sociala_\%c4\%aastermi\%c5\%86a\%20statistikas\%20dati_Darba\%20samaksa\&px_language=en\&px_ $\mathrm{db}=$ Sociala\&rxid=cdcb978c-22b0-416a-aacc-aa650d3e2ce0 [accessed 2014-05-14].

Central Statistical Bureau of Latvia. (2014). Main entrepreneurship indicators in trade by statistical region. Available at: http://data.csb.gov.lv/Table.aspx?layout=tableViewLayout1\&px_tableid=TI0021_euro.px\&px_path=rupnbuvn Ikgad\%c4\%93jie\%20statistikas \%20dati_Iek\%c5\%a1 zemes $\% 20$ tirdzniec $\%$ c 4\%abba\%20un $\% 20$ maksas $\% 20$ pakalpojumi\&px_language=en\&px_db=rupnbuvn\&rxid=cdcb978c-22b0-416a-aacc-aa650d3e2ce0 [accessed 2014-05-15].

Central Statistical Bureau of Latvia. (2014). Population by sex and by main age group by statistical region. Available at: http://data.csb.gov.lv/Table.aspx?layout=tableViewLayout1\&px_tableid=IS0180.px\&px_path=Sociala Ikgad\%c4\%93jie\%20statistikas\%20dati_Iedz\%c4\%abvot $\%$ c4\%81ji_Iedz $\%$ c4\%abvot $\%$ c4\%81ji $\% 20$ skaits $\% 20$ 
un\%20t\%c4\%81\%20izmai\%c5\%86as\&px_language=en\&px_db=Sociala\&rxid=19100e33-6a5b-429f-af6413a44f275c18 [accessed 2014-05-15].

Central Statistical Bureau of Latvia. (2014). Population number and its change by statistical region. Available at: http://data.csb.gov.lv/Table.aspx?layout=tableViewLayout1\&px_tableid=IS0032.px\&px_path=Sociala Ikgad $\%$ c4\%93jie $\% 20$ statistikas $\% 20$ dati_Iedz $\%$ c4\%abvot $\%$ c4\% $\% 1$ ji_Iedz $\%$ c4\%abvot $\%$ c4\%81ji\%20skaits $\% \overline{20}$ un $\% 20 t \% c 4 \% 81 \% 20 i z m a i \% c 5 \% 86 a s \& p x \_l a n g u a g e=e n \& p x \_d b=$ Sociala\&rxid=19100e33-6a5b-429f-af6413a44f275c18 [accessed 2014-05-15].

Chang, H. J., Eckman, M., Yan, R. N. (2011). Application of the Stimulus-Organism-Response model to the retail environment: the role of hedonic motivation in impulse buying behaviour. The International Review of Retail, Distribution and Consumer Research, Vol. 21(3), p. 233-249. Available at DOI: 10.1080/09593969.2011.578798 [accessed 2013-10-03].

Euromonitor International. (2014) Non-grocery-retailers in Latvia. Available at: http://www.euromonitor.com/nongrocery-retailers-in-latvia/report [accessed 2014-05-18].

Jayasankaraprasad, C., Kathyayani, G. (2013). Cross-format shopping motives and shopper typologies for grocery shopping: multivariate approach. The International Review of Retail, Distribution and Consumer Research. Available at: http://dx.doi.org/10.1080/09593969.2013.801358 [accessed 2013-10-03].

LETA Biznesa portals. (2014). About top! Available at: http://nozare.lv.resursi.rtu.lv/nozares/trade/uznemumi/item/ B56A80B0-C9FC-4277-B2C5-754A23650E15/ [accessed 2014-05-12].

LETA Biznesa portals. (2014). About aibe. Available at: http://nozare.lv.resursi.rtu.lv/nozares/trade/uznemumi/item/ F8EB429D-DFC3-4507-854A-C7935ACED998/ [accessed 2014-05-12].

LETA Biznesa portals. (2014). About Maxima. Available at: http://nozare.lv.resursi.rtu.lv/nozares/trade/uznemumi/ item/0625334A-2541-4754-900B-AF0660699301/ [accessed 2014-05-12].

LETA Biznesa portals. (2014). About RIMI. Available at: http://nozare.lv.resursi.rtu.lv/nozares/trade/uznemumi/item/ F7D9DC3D-AC39-11D4-9D85-00A0C9CFC2DB/ [accessed 2014-05-12].

Levy, M. (1998) Retailing Management. 3.ed. IRWIN: McGraw-Hill, p. 98-103.

N'jumjen, J., Kallen, Р. (2005). Розничная торговля: организация и управление. Питер, с. 24-27.

Solka, A., Jackson, V. P., Min-Young, L. (2011). The influence og gender and culture on Generation Y consumer decision making styles. The International Review of Retail, Distribution and Consumer Research, Vol. 21 (4), p. 391-409. Available at DOI: 10.1080/09593969.2011.596554 [accessed 2013-10-03].

Solomon, M. R. (2006). Consumer behavior: buying, selling and being. 7th.ed., p. 512-514.

Supermarket chain. (2014). About top! Available at: http://www.toppartika.lv/supermarket [accessed 2014-05-13].

Берман, Б., Эванс, Д. Р. (2003). Розничная торговля: стратегический подход. 8-ое издание. Москва: Вильямс, c. $280-282$.

\title{
MAŽMENINÉS PREKYBOS PARDUOTUVIŲ PLÉTRA VARTOTOJŲ ELGSENOS IR REGIONO KONTEKSTE
}

\author{
IEva Andersone, Rita Greitane \\ Rygos technikos universitetas (Latvija)
}

\section{Santrauka}

Šio straipsnio tikslas - išanalizuoti mažmeninès prekybos parduotuvių paplitimą Latvijos regionuose ir Latvijos vartotojų elgseną. Remdamiesi prieinamais statistiniais duomenimis ir savo tyrimo rezultatais, autoriai išanalizavo didžiausių mažmeninès prekybos parduotuvių pasiskirstymą Latvijos regionuose ir vartotojų elgseną mažmeninėje prekyboje. Tyrimo metu apibréžtas parduotuvių konsultantų vaidmuo pirkimo procese, tyrimo rezultatai ịvertinti kartų požiūriu. Šie rezultatai gali padèti mažmeninės prekybos bendrovèms dirbti efektyviau, pasirinkus tinkamą mažmeninès prekybos parduotuvès tipą.

PAGRINDINIAI ŽODŽIAI: vartotojų elgsena, mažmeninè prekyba, mažmeninès prekybos parduotuviu rūšys, kartos. 